\title{
Government Public Information Disclosure Supporting System : The Implications Of Disruptive Technology For Ministry Of Finance Public Information Services in Indonesia
}

\author{
Reinaldy Ferdiansyah ${ }^{1}$, Andre Noevi Rahmanto ${ }^{2}$, Yulius Slamet ${ }^{3}$ \\ 1,2,3 Magister of Communication Science Program, Sebelas Maret University, Surakarta, Indonesia \\ ${ }^{1}$ reinaldy.ferdiansyah@student.uns.ac.id, ${ }^{2}$ andreyuda@gmail.com, ${ }^{3}$ yuliusslamet48@gmail.com
}

\begin{abstract}
This article is based on changing patterns of behavior in the digital age, especially in government public information disclosure. Internet of Things (IoT) has become a basic need of the people accompanied by technological disruption, becoming a challenge for the government in providing easy and fast access to information. This research was conducted to see the implications of using new media in the Ministry of Finance's public information service process from 2015 to the present. Using descriptive analytic qualitative research methods, semi-structured interview techniques, and observation participatory as a data collection, the results of the study provide an explanation that granting easy public access through new media can also support the simplification of bureaucracy. The implication is, organizational culture will always adjust to the development by information technology use. Furthermore, the results are expected to be used as positive input in the implementation of information disclosure in the government area.
\end{abstract}

Keywords: Public Information Access, Disruptive Technology, Shifting, Sustainable Development, Organizational Culture.

\section{Introduction}

Easy access to government public information is one of the people's rights to obtain public information. Availability and access to information must be the government's top priority regardless of the methods used such as collection, storage and dissemination [1]. Thus, the rights of the community to communicate, develop their personal and social environment, and seek, obtain, and convey information can be fulfilled [2].

Providing good government access to information encourages less restriction. During carrying out operational tasks, public organizations certainly produce, collect, manage, and store information [3][4][5]. This encourages the importance of transparency and accountability of the government along with the increasing demand for information which makes the government must be more participatory and innovative in providing services to the public sector [6][7].

Fulfillment of the basic rights of the people to obtain information from the government has been regulated in the Law and must be implemented by all Public Agencies, including the Ministry of Finance [8]. The implementation of public information disclosure within the Ministry of Finance is carried out by the Ministry of Finance Information and Documentation Management Officer (PPID MoF). From 2014 to 2019, PPID MoF has always received the 
best title in ranking Public Information Openness based on the results of monitoring and evaluation conducted by the Central Information Commission [9]. This success is in line with the PPID MoF commitment in realizing a good state administration, which is transparent, effective and efficient, accountable and can be accounted for [8].

In the Digital Age, society has changed and formed from technological innovation and information revolution. The development and dissemination of information and technology flows such as through the internet and smartphones have a significant impact on world society and shape virtual culture [10][11]. Technological developments affect traditional government governance. People who are starting to get acquainted with the Internet of Things (IoT) will bring up an era of technological disruption that encourages governments to innovate, because it influences people's views [12][13]. Thus, the current government must face the promise and challenge of providing information and relate to the level of communication and interaction with the changes in tools used and applications [14]. Some Issues relating to changes in the community's environment and how we work can be adapted to create sustainable development [15].

Some of the previous studies, discussed more about the process of implementing Law number 14 of 2008 conducted by public bodies in general. In this study, looking at the condition of interest in achieving the goal of public information disclosure managed PPID $\mathrm{MoF}$ in the era of technological disruption, researchers felt the need to conduct research on the effect of using new media in the process of public information service PPID MoF to access public information and its implications for changing organizational culture.

In connection with this, the element or element of communication under study is the PPID $\mathrm{MoF}$ as an organizational communicator. Researchers want to see whether by utilizing new media, PPID MoF can carry out a communication process that can give effect to the ease of access to the public and simplify the bureaucracy in the activities of public information services within the Ministry of Finance.

\section{Literature Review}

\subsection{PPID MoF and Public Information Access}

Public information services can run well if public access to government information is easy. Consistent information delivery and service responses need to be provided through various channels by the government to citizens [16]. Therefore, the government needs to prepare several strategies to overcome limitations and create strategic value in increasing public trust, namely by utilizing technology through investments in various communication channels commonly used such as television, social media, smart devices, and others [17][18].

\subsection{Disruptive Technology}

Disruptive technology will cause an innovation. Implications must be considered from the perspective of secondary stakeholders. Innovation allows for an impact on the social environment and provides great benefits [19]. To reach out to stakeholders, measurable innovation needs to be done through technology development and will influence the uncertainty of social change [20][21]. 
Disruptive technology can cause changes in work patterns and service standards that are usually done by the government. The potential to reshape service standards is possible when technological innovation is successfully implemented. Thus, adjustments to technological changes can cause opposition or rejection from those who have been responsible for the work process and existing infrastructure [22].

\subsection{Shifting}

In the governance process, change will be triggered by various interrelated factors. Change can be initiated by the government itself, influenced by the needs of the community, as well as the transformation of the relationship between the two. In this digital era, changes to the granting of access to society will be able to depend on the internet [23][24]. Changes see cultural background, knowledge, and beliefs in the use of language, thoughts, and actions [25].

Changes in the way they talk, think and act can be attributed to Blending theory. Theory has many similarities with pragmatic aesthetics and explains how the construction of online meanings is done on the basis of learning and new knowledge. This can be done on the basis of experience or everyday situations [26][27][28][29].

\subsection{Sustainable Development and Organizational Culture}

Sustainable development can be adapted to organizational conditions. The concept of the main dimensions of sustainable development is global, so that the concept of sustainable development planning is adopted to adjust the needs of science, institutions, and institutions and can be developed with various concepts [30].

In communication practices, transparency will improve government governance and the flow of information to the public that is becoming increasingly active [31]. Sustainable development will always be in line with the process of changing the broader organizational culture. Almost all aspects of organizational life are influenced by organizational culture in how to treat stakeholders, firm rules, and the organizational climate. For this reason, behavior, norms and values in an organization are important characteristics to support this [32][33]. In government and organizations, what appears is technology and product [34].

\section{Method}

\subsection{Data Collection}

The researcher uses primary data obtained through a semi-structured interview process and observation. Semi-structured interviews are used to understand the relationships between variables when collecting empirical data and answering research questions [35]. Meanwhile, to obtain secondary data, researchers conducted an analysis of books, journals, related official documents, Ministry of Finance website, PPID MoF social media, and seminars related to qualitative content analysis methods, which systematically illustrate the importance of context in determining meaning [36][37]. In general, data collection techniques vary through six sources of evidence such as documentation, archives, direct observation, participant observation, physical artifacts, and interviews [38]. 


\subsection{Data Analysis and Research Quality}

Furthermore, research can provide depth and understanding of existing problems by revealing the informant's perspective [39]. Based on the researcher's perspective, the findings may also be generalized to various contexts or settings [40]. In this case, the quality of all parts of the study must be ascertained and can be achieved by the validity, reliability, and research ethics [38]. In addition, the validity of the data is obtained by using four criteria, namely (1) credibility, (2) transferability, (3) dependability, and (4) confirmability.

\section{Results and Discussion}

\subsection{Disruptive Technology and Shifting on Public Access}

Public access to the Ministry of Finance's public information is provided through the Public Information service channel to facilitate applicants to submit information requests. The provision of government channels in providing information is in line with the creation of strategic value in increasing public trust, one of which is by utilizing technology through several communication channels [16][17][18]. PPID MoF provides this facility through officers at the Public Information Service Room, email ppid.kemenkeu@kemenkeu.go.id, the request for information page on the Ministry of Finance's e-PPID website (http://eppid.kemenkeu.go.id/ ), as well as the PPID MoF mobile application (available on the AppStore and PlayStore).

Requests for public information entered through the e-PPID and mobile PPID applications are processed through the PPID MoF backoffice service using the SIPPID application (http://sippid.e-prime.kemenkeu.go.id/) based on the internet. Through the SIPPID application, information service officers can see the identity of the applicant and print the application form directly. Furthermore, if there are developments in the request for information, the SIPPID application will automatically send a notification via email to the Applicant. This is in line with research related to Disruptive technology that can cause changes in work patterns and service standards that are commonly carried out by the government. technological innovation is applied and must be adapted to technological change [22].

The benefits of using new media can be felt by information applicants in terms of access to services, as well as public information service officers in terms of managing public information services. The internet-based application submission channel is provided, in line with the shifting patterns of public communication towards digital. In this regard, the PPID MoF and PPID MoF management officer board need to be supported by a capable information system (backoffice). Therefore, in 2018 the development of the 2nd generation SIPPID based on the internet and not the intranet is the same as the 1st generation SIPPID. Changes that occur in accordance with previous research where the change can be initiated by the government itself, influenced by the needs of the community, as well as both of them transformation In this digital era, changes to the granting of access to society will be able to depend on the internet [23][24].

Submitting an application through the e-PPID and mobile PPID Ministry of Finance applications has the following advantages to make it easy for the applicant to access and submit requests for public information to the PPID of the Ministry of Finance and applicants can directly request information controlled by echelon I units, without difficulty in 
determining which units should be targeted for information, because the information service officer will immediately identify and submit requests to Level I PPID. This was done by the Ministry of Finance PPID to change the way they talk, think and act in the process of public information services. Changes related to Blending theory explain how the construction of online meaning is carried out on the basis of learning and new knowledge [26][27][28][29].

Researchers found that disruption technology greatly affected the Ministry of Finance's PPID public information service process. Since 2015, there has been a shift in work processes that were previously done manually using technology. Public access to the internet makes PPID of the Ministry of Finance have to innovate so that services can be carried out quickly and easily accessed. Several applications have been made to prove that PPID of the Ministry of Finance uses technology as a way to change work patterns to face social changes in society in the digital era.

\subsection{Sustainable Development and Organizational Culture for PPID Kemenkeu}

With the increasing access of Indonesians to the internet, from $29 \%$ in 2013 to $56 \%$ in 2017 (Google Consumer Barometer 2017), has an impact on the increasing number of information applicants [ppid annual report]. In order to maintain commitment as the best, from 2015 to 2019, the PPID MoF has utilized new media and simplified the process of public information services that can be accessed by the public. This was implemented with the presence of PPID MoF website (2015), the E-PPID web application (2015), and the PPID mobile (2018).

Based on statistical requests for information with total requests for information coming through PPID MoF of 8535 requests (at the time this article was compiled), PPID MoF is also developing the second generation E-PPID web application (2019-present), and mobile PPID version 2.0 [41][42]. Thus, in accordance with previous research that sustainable development is adopted to adjust organizational conditions and can be developed with a variety of concepts because sustainable development is global [30]. With sustainable development, the Government will always try to change for the better and transparent. Technology can help improve government governance and information flow to the community [31].

To ensure the PPID MoF information service activities in the era of disruptive technology and changing patterns of society, the use of technology must be able to run effectively and be supported by an appropriate organizational work culture. This has become important in the successful implementation of technology in sustainable development. The process of changing the work culture of the organization can be seen from the existence of new roles and tasks that are accepted and carried out by public information service officers within the Ministry of Finance. The process is in line with the opinion of some researchers that sustainable development will always be in line with the process of change in all aspects of organizational life. The process is influenced by an increasingly broad organizational culture with regard to organizational characteristics [32][33].

In this study, it was found that the important role of HR in supporting organizational culture change is needed. It is also evident that there is support from the organization to make these changes by implementing employee competency enhancement activities and strengthening information service materials. The organizational culture must be considered in order to realize sustainable development, because when the organizational culture does not change, it will be impossible for the Government to carry out a sustainable development program. Communication for sustainable development is an integrated and holistic approach that contrast and share the reality of different stakeholders. Furthermore, technological 
products and human resources that appear are a reflection of government work that can be felt, heard and seen by the public. That way, PPID MoF must ensure that changes in organizational culture go well in supporting sustainable development.

\section{Conclusion}

The implementation of public information disclosure within the government must be done professionally and transparently. To be able to provide responsive public information services in the current digital era, PPID MoF must be able to adapt to technological developments and community needs. Mandate of Law Number 14 Year 2008 regarding Openness of Public Information so that every Public Information must be obtained by every Public Information Applicant quickly and on time, at a low cost, and simple ways also provide motivation for PPID from the Ministry of Finance to continue to innovate especially in services information technology. Of course, innovation becomes more useful if it is accompanied by strengthening synergy and collaboration. So that it can withstand the flow of change very quickly. Thus, PPID MoF is able to carry out appropriate communication processes that can have an impact on ease of access to the public and simplification of bureaucracy in public information service activities within the Ministry of Finance.

\section{References}

[1] A. Yannoukakou and I. Araka, "Access to Government Information: Right to Information and Open Government Data Synergy,” Procedia - Soc. Behav. Sci., vol. 147, pp. 332-340, 2014, doi: 10.1016/j.sbspro.2014.07.107.

[2] R. Indonesia, Undang-Undang Dasar Negara Republik Indonesia Tahun 1945. Sekretariat Jenderal MPR RI, 2002.

[3] K. B. Allen, “Access to government information,” Gov. Inf. Q., vol. 9, no. 1, pp. 67-80, 1992.

[4] P. Birkinshaw, "Freedom of information and open government: The European community/union dimension," Gov. Inf. Q., vol. 14, no. 1, pp. 27-49, 1997.

[5] A. Meijer and M. Thaens, "Public information strategies: Making government information available to citizens," Inf. Polity, vol. 14, no. 1, 2, pp. 31-45, 2009.

[6] J. Gray and H. Darbishire, "Beyond access: Open government data \& the right to (re) use public information," Access Info Eur. Open Knowl., 2011.

[7] K. Janssen, "Open government data and the right to information: Opportunities and obstacles," J. Community Informatics, vol. 8, no. 2, 2012.

[8] P. R. Indonesia, "Undang-undang Republik Indonesia nomor 14 tahun 2008 tentang keterbukaan informasi publik," 2008.

[9] K. Keuangan, "Laporan unpublished (Rangkuman Berita Kemenkeu)," 2020. https://www.kemenkeu.go.id.

[10] C. Leitner and C. M. Stiefmueller, "Disruptive Technologies and the Public Sector: The Changing Dynamics of Governance," in Public Service Excellence in the 21st Century, Springer, 2019, pp. 237-274.

[11] R. Sugihartati, Perkembangan masyarakat informasi \& teori sosial kontemporer. Kencana, 2014.

[12] R. M. D. Putra and others, "Inovasi Pelayanan Publik Di Era Disrupsi (Studi Tentang Keberlanjutan Inovasi E-Health Di Kota Surabaya)," Universitas Airlangga, 2018.

[13] E. U. Commission and others, "Powering European Public Sector Innovation: Towards a New 
Architecture," Rep. Expert Gr. public Sect. Innov. EUR 13825 EN, 2013.

[14] J. R. Gil-Garcia, Enacting electronic government success: An integrative study of governmentwide websites, organizational capabilities, and institutions, vol. 31. Springer Science \& Business Media, 2012.

[15] Skolverket, "Curriculum for the compulsory school, preschool class and the recreation centre 2011." Skolverket Stockholm, 2011.

[16] C. G. Reddick and M. Turner, "Channel choice and public service delivery in Canada: Comparing e-government to traditional service delivery," Gov. Inf. Q., vol. 29, no. 1, pp. 1-11, 2012.

[17] S. K. Kim, M. J. Park, and J. J. Rho, "Effect of the Government's Use of Social Media on the Reliability of the Government: Focus on Twitter," Public Manag. Rev., vol. 17, no. 3, pp. 328$355,2015$.

[18] S. K. Kim, M. J. Park, and J. J. Rho, "Does public service delivery through new channels promote citizen trust in government? The case of smart devices," Inf. Technol. Dev., vol. 25, no. 3 , pp. 604-624, 2019.

[19] J. K. Hall and M. J. C. Martin, "Disruptive technologies, stakeholders and the innovation valueadded chain: a framework for evaluating radical technology development," $R \& d$ Manag., vol. 35, no. 3, pp. 273-284, 2005.

[20] A. A. Elias, R. Y. Cavana, and L. S. Jackson, "Stakeholder analysis for R\&D project management," R\&D Manag., vol. 32, no. 4, pp. 301-310, 2002.

[21] J. E. Post, L. E. Preston, and S. Sachs, "Managing the extended enterprise: The new stakeholder view," Calif. Manage. Rev., vol. 45, no. 1, pp. 6-28, 2002.

[22] C. Christensen, "Key concepts--disruptive innovation," Clayt. Christ. www. claytonchristensen. com, 2014.

[23] S. Qureshi, "Networks of change, shifting power from institutions to people: how are innovations in the use of information and communication technology transforming development?" Taylor \& Francis, 2013.

[24] M. Castells, Networks of outrage and hope: Social movements in the Internet age. John Wiley \& Sons, 2015

[25] Z. Kovecses, Language, mind, and culture: A practical introduction. Oxford University Press, 2006.

[26] G. Fauconnier and M. Turner, "Conceptual integration networks," Cogn. Sci., vol. 22, no. 2, pp. 133-187, 1998.

[27] T. Fauconnier, "G. F auconnier, M. T urner," W. we think Concept. blending mind's hidden complexities, 2002.

[28] M. G. Petersen, O. S. Iversen, P. G. Krogh, and M. Ludvigsen, "Aesthetic interaction: a pragmatist's aesthetics of interactive systems," in Proceedings of the 5th conference on Designing interactive systems: processes, practices, methods, and techniques, 2004, pp. 269276.

[29] J. McCarthy and P. Wright, "Technology as experience Cambridge," MA MIT Press. Sch., 2004.

[30] Y. Kusumarini, "Konstruksi Teori Sustainable Interior Design: Pendekatan Holistik Eco-SocioEcono Interior Design Kontekstual di Indonesia,” Institut Teknologi Sepuluh Nopember, 2015.

[31] J. Servaes, "Communication policies, good governance and development journalism," Commun. South African J. Commun. Theory Res., vol. 35, no. 1, pp. 50-80, 2009.

[32] S. W. Littlejohn, K. A. Foss, and J. G. Oetzel, "The Theory of Human Communication. Illinois." Waveland Press, Inc, 2017.

[33] O. Ojo, "Organisational culture and corporate performance: Empirical evidence from Nigeria," J. Law Gov., vol. 5, no. 2, 2010.

[34] E. H. Schein, "Organizational Culture and Leadership, 4th Edn San Francisco." CA: JosseyBass.[Google Scholar], 2010.

[35] M. Saunders, P. Lewis, and A. Thornhill, "Research methods for business students Seventh Edition." Harlow, England: Pearson Education Limited, 2016.

[36] U. Flick, The SAGE handbook of qualitative data analysis. Sage, 2013. 
[37] K. Krippendorff, Content analysis: An introduction to its methodology. Sage publications, 2018.

[38] R. K. Yin, "Case study research and applications." Sage, 2018.

[39] T. R. Lindlof and B. C. Taylor, Qualitative communication research methods. Sage publications, 2017.

[40] J. Ritchie, J. Lewis, C. M. Nicholls, R. Ormston, and others, Qualitative research practice: A guide for social science students and researchers. sage, 2013.

[41] P. K. Keuangan, "Laporan Tahunan Layanan Informasi Publik," 2020. http://www.eppid.kemenkeu.go.id/in/post/laporan-layanan (accessed Jul. 29, 2020).

[42] PPID, "Statistik permohonan Informasi," 2020. http://www.eppid.kemenkeu.go.id/in/page/statistic-chart (accessed Jul. 29, 2020). 